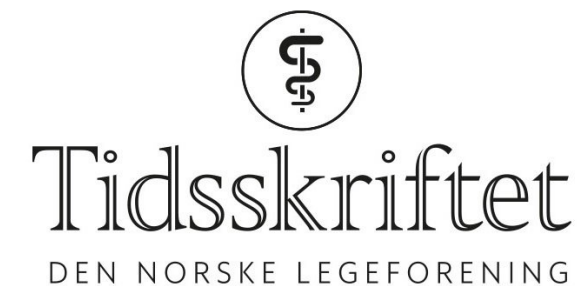

DEN NORSKE LEGEFORENING

\title{
Tidlig innsats er viktig ved atferdsvansker hos barn
}

KOMMENTAR

\section{STEINAR KONRADSEN}

E-post: steinar.konradsen@lenvik.kommune.no Steinar Konradsen er assisterende kommuneoverlege og tilknyttet Senjalegen Ingen oppgitte interessekonflikter.

\section{HENRIETTE KONRADSEN}

Henriette Konradsen er psykolog i Oslo kommune Ingen oppgitte interessekonflikter.

Øyen og medforfattere peker på at utredning og behandling av barn med atferdsvansker er et viktig felt hvor mye sykelighet kan forebygges (1). At det viktigste vi kan lære av denne kasuistikken er fordelene ved tverrfaglig samarbeid, bred utredning og flere behandlingstiltak, mener vi er en feilaktig konklusjon. Artikkelen peker på en systemsvakhet som det er viktigere å adressere.

Guttens symptomer hadde utviklet seg over flere år. Han ble utredet av mange spesialister før det ble stilt en diagnose og før det ble iverksatt tiltak for å rette på problemet. Det er etter vår mening tydelig at fagpersonene som har kompetanse på atferdsvansker hos barn, var alt for langt unna barnet og familien. Gutten har kjente risikofaktorer for atferdsvansker, og problemene hadde vært tilstede i lang tid før foreldrene fikk hjelp fra helsevesenet. Tidlig identifikasjon og iverksetting av tiltak kunne trolig ha forebygget de omfattende problemene.

Forfatterne skriver at rollefordelingen ofte er uklar når det gjelder oppfølgingen av barn med komplekse tilstander. Vi tror imidlertid ikke dette handler om uklar rollefordeling. Hovedproblemet er mangel på ressurser og kompetanse i førstelinjetjenesten. Førstelinjen bør ha kompetanse til å fange opp problemer tidlig og til å sette i verk tiltak parallelt med eventuelle tiltak i spesialisthelsetjenesten.

For å få dette til trenger vi en kraftig styrking av førstelinjetjenesten. Det er stort behov for fagpersoner med sterk tilknytning til barnehagene, som kan tilby veiledning til foreldre og barnehageansatte. Da vil det være mulig å fange opp vansker tidlig, og tiltak kan settes i verk før vanskene har fått vokse. I dette tilfellet kunne både barnehagen og foreldrene fått hjelp da de begynte å se at gutten strevde. Flere steder i Norge jobbes det på denne måten (2).

De siste årene har det kommet dokumentasjon på “tidlig innsats” (3-5). Denne kasuistikken belyser betydningen av å sette i verk tiltak tidlig. Ressursene må flyttes nærmere barna. Dette vil trolig kunne forebygge mange slike problemer og videre psykisk sykdom. Etter vår 
oppfatning er dette den absolutt viktigste lærdommen i artikkelen.

LITTERATUR:

1. Øyen AS, Ulleberg B, Sangar P et al. En gutt med hjertefeil og atferdsvansker. Tidsskr Nor Legeforen 2017; 137. DOI: 10.4045/tidsskr.17.0198. [PubMed][CrossRef]

2. Halvorsen P. - Joda, psykologkompetanse lønner seg. Norsk psykologforening.

https://www.psykologforeningen.no/foreningen/nyheter-og-kommentarer/aktuelt/joda-psykologkom petanse-loenner-seg (23.11.2017).

3. Halvorsen P. - Kommunen sitter med nøkkelen til god psykisk helse. Norsk psykologforening. https://www.psykologforeningen.no/politikk/psykolog-i-kommunen/psykolog-i-foerstelinjen-eksemp ler-2009-2014/kommunen-sitter-med-noekkelen-til-god-psykisk-helse (23.11.2017).

4. Heckman JJ. Invest in early childhood development: Reduce deficits, strengthen the economy. The Heckman Equation, 2012.

https://heckmanequation.org/assets/2013/o7/F_HeckmanDeficitPieceCUSTOM-Generic_052714-3-1.pdf (23.11.2017).

5. Nilsen W, Kjeldsen A, Karevold EB et al. Cohort Profile: The Tracking Opportunities and Problems Study (TOPP)-study of Norwegian children and their parents followed from infancy to early adulthood. Int J Epidemiol 2017; 46: 1399 -1399g. [PubMed][CrossRef]

Publisert: 8. januar 2018. Tidsskr Nor Legeforen. DOI:10.4045/tidsskr.17.109o

(C) Tidsskrift for Den norske legeforening 2020. Lastet ned fra tidsskriftet.no 